\title{
Synthesis and Antibacterial, Antioxidant, and Molecular Docking Analysis of Some Novel Quinoline Derivatives
}

\author{
Digafie Zeleke, ${ }^{1}$ Rajalakshmanan Eswaramoorthy (i), ${ }^{1}$ Zerihun Belay, ${ }^{2}$ \\ and Yadessa Melaku $\mathbb{D}^{1}$ \\ ${ }^{1}$ Department of Applied Chemistry, Adama Science and Technology University, Adama, Ethiopia \\ ${ }^{2}$ Department of Applied Biology, Adama Science and Technology University, Adama, Ethiopia \\ Correspondence should be addressed to Yadessa Melaku; yadessamelaku2010@gmail.com
}

Received 9 March 2020; Revised 8 June 2020; Accepted 19 June 2020; Published 24 July 2020

Academic Editor: Ponnurengam Malliappan Sivakumar

Copyright (C) 2020 Digafie Zeleke et al. This is an open access article distributed under the Creative Commons Attribution License, which permits unrestricted use, distribution, and reproduction in any medium, provided the original work is properly cited.

\begin{abstract}
2-Chloroquinoline-3-carbaldehyde and 2-chloro-8-methylquinoline-3-carbaldehyde derivatives were synthesized through Vilsmeier formulation of acetanilide and N-(o-tolyl)acetamide. Aromatic nucleophilic substitution reaction was used to introduce various nucleophiles in place of chlorine under different reaction conditions. The carbaldehyde group was oxidized by permanganate method and reduced with metallic sodium in methanol and ethanol. The synthesized compounds were characterized by UV-Vis, IR, and NMR. The antibacterial activity of the synthesized compounds was screened against two Gram-positive bacteria (Bacillus subtilis ATCC6633 and Staphylococcus aureus ATCC25923) and two Gram-negative bacteria (Escherichia coli ATCC 25922 and Pseudomonas aeruginosa ATCC 27853). Most of the compounds displayed potent activity against two or more bacterial strains. Among them, compounds $\mathbf{6}$ and $\mathbf{1 5}$ showed maximum activity against Pseudomonas aeruginosa with mean inhibition zones of $9.67 \pm 1.11$ and $10.00 \pm 0.44 \mathrm{~mm}$, respectively, while ciprofloxacin showed mean inhibition zone of $8.33 \pm 0.44 \mathrm{~mm}$ at similar concentration. On the other hand, compound 8 exhibited maximum activity against Escherichia coli with inhibition zones of about $9.00 \pm 0.55 \mathrm{~mm}$ at $300 \mu \mathrm{g} / \mathrm{mL}$ and $11.33 \pm 1.11 \mathrm{~mm}$ at $500 \mu \mathrm{g} / \mathrm{mL}$. The radical scavenging activity of these compounds was evaluated using 1,1-diphenyl-2-picryl hydrazyl (DPPH), and all of them displayed moderate antioxidant activity, with compound 7 exhibiting the strongest activity. The molecular docking study of the synthesized compounds was conducted to investigate their binding pattern with DNA gyrase, all of them were found to have minimum binding energy ranging from -6.0 to $-7.33 \mathrm{kcal} / \mathrm{mol}$, and the best result was achieved with compound 11. The findings of the in vitro antibacterial and molecular docking analysis demonstrated that the synthesized compounds have potential of antibacterial activity and can be further optimized to serve as lead compounds.
\end{abstract}

\section{Introduction}

Antibacterial therapy has been challenging because of the alarming rate in rise of infections caused by bacteria coupled with their resistance to most of first-line antibiotic agents [1]. This is a serious threat to human health of the world in the $21^{\text {st }}$ century and urgently calls continuing research to find out compounds possessing better antimicrobial with broadspectrum activities. Hence, designing new drugs to treat disease and inflammations without causing significant side effects on patients is very important. In view of this, quinoline derivatives are among important compounds previously reported to have a wide arrays of biological activities [2,3]. Therefore, introduction of different functional groups on quinoline scaffold is a very good idea for the development of new drug.

The discovery of nalidixic acid in 1962, along with its introduction for clinical use in 1967, marks the beginning of decades of quinolone development and use [4]. Since then, various fluoroquinolones have been synthesized and used to treat various bacterial infections for decades [4]. However, currently some of them have been removed from market due 
to intolerable side effects; in addition, some bacteria have also developed resistance against them and have narrowed their spectrum of activities [5].

In general, fluoroquinolones underwent four generations of development and improvement since the discovery of nalidixic acid, with each subsequent generation exhibiting broader and stronger bioactivity and less side effects than the previous one $[5,6]$. Oxolinic acid, pipemidic acid, and nalidixic acid belong to the first generation and were used for the treatment of urinary tract infection caused by the majority of Gram-negative bacteria; however, all of them have short lifetime [6].

Enoxacin, ofloxacin, lomefloxacin, norfloxacin, and ciprofloxacin are in the second generation, have longer halflife, and improved activity against Gram-negative bacteria compared to the first generation [6,7]. Sparfloxacin, grepafloxacin, and temafloxacin belong to the third generation [8] and are used as oral broad-spectrum antibacterial agents in the treatment of acute bacterial exacerbation of chronic bronchitis and mild-to-moderate pneumonia [9].

Gatifloxacin, clinafloxacin, trovafloxacin, and moxifloxacin belong to the fourth generation of fluoroquinolone drugs, which display extended activity against both Gramnegative and -positive bacteria strains; additionally, they are active against anaerobes and atypical bacteria [10].

Besides fluoroquinolone-based drugs, 2-chloroquinoline-3-carbaldehyde derivatives have also attracted much attention due to their considerable biological and pharmacological activities including antimicrobial [8], anti-inflammatory [11-13], antimalarial [14, 15], anticancer [16], antiviral $[17,18]$, and antifungal activities $[19,20]$. Inspired by these reports, we have designed and synthesized various quinoline-3-carbaldehyde derivatives and evaluated their antibacterial and radical scavenging activities. Also incorporated herein is the in silico molecular docking analysis of the synthesized derivatives of quinolines.

\section{Materials and Methods}

2.1. General. Melting points were determined using open capillary tubes (Thiele) and were uncorrected. Analytical TLC was run on a $0.2 \mathrm{~mm}$ thick layer of silica gel $\mathrm{GF}_{254}$ (Merck) on aluminum plate. Spots were detected using UV lamp. Column chromatography was performed using silica gel 60 (250-400 mesh) Merck. The IR spectra of compounds were recorded using a Perkin-Elmer BX Spectrometer $\left(400-4000 \mathrm{~cm}^{-1}\right)$ as $\mathrm{KBr}$ pellets. NMR spectra were recorded using Bruker Avance 400 spectrometer operating at $400 \mathrm{MHz}$ using $\mathrm{CDCl}_{3}$ and DMSO-d6 as a solvent. All chemicals were purchased from Loba Chemie PVT, Ltd.

\subsection{Chemistry}

2.2.1. Synthesis of Acetanilide (3). In $250 \mathrm{~mL}$ round flask, aniline $(20 \mathrm{~mL})$, acetic anhydride $(22 \mathrm{~mL})$, zinc powder $(0.2 \mathrm{~g})$, and acetic acid $(23 \mathrm{~mL})$ were added. The mixture was boiled under reflux using water condenser for an hour. Then, it was cooled to room temperature and poured into $200 \mathrm{~mL}$ of crushed ice water. The solid product was collected by suction filtration. White crystal; yield $69 \%$, mp $112-113^{\circ} \mathrm{C}$ (Lit. $\mathrm{mp} 114.3^{\circ} \mathrm{C}$ ).

2.2.2. Synthesis of 2-Chloroquinoline-3-carbaldehyde (4). $\mathrm{N}, \mathrm{N}$-dimethylformamide $(20 \mathrm{~mL}, 0.26 \mathrm{~mol})$ was added to a $100 \mathrm{~mL}$ round-bottom flask guarded with drying tube; it was cooled to $0^{\circ} \mathrm{C}$ using ice bath. Then, phosphorus oxychloride $(70 \mathrm{~mL}, 0.75 \mathrm{~mol})$ was added dropwise to it from dropping funnel guarded by drying tube while being stirred by magnetic stirrer. This addition was done for 30 minutes. Then acetamide $(13.5 \mathrm{~g}, 0.1 \mathrm{~mol})$ was added to it. After 5 minutes, the dropper funnel was replaced by air condenser with guarding tube at its end, and the mixture was heated for 22 hours on oil bath at $85-90^{\circ} \mathrm{C}$. Then it was cooled to room temperature, poured into a beaker containing $400 \mathrm{~mL}$ crushed ice water, and stirred for 20 minutes. The yellow solid product was collected by suction filtration and washed with $100 \mathrm{~mL}$ cold water. The crude yield was $11.5 \mathrm{~g}(60 \%)$ and was recrystallized from ethyl acetate. yellow crystal; mp $146-148^{\circ} \mathrm{C}$; yield $48.5 \%$; $R_{\mathrm{f}}=0.22 \quad(n$-hexane $:$ EtOAc $=9: 1) ; \quad \mathrm{UV}$-Vis $\quad(\mathrm{MeOH})$ $\lambda_{\text {max }}=280 \mathrm{~nm}$; IR ( $\left.\mathrm{u} \mathrm{cm}{ }^{-1}, \mathrm{KBr}\right): 3035$ (CH-arom.), 1693 ( $\mathrm{C}=\mathrm{O}$ aldehyde), 1621 (quinoline $\mathrm{C}=\mathrm{N}$ str.), 599 (aromatic $\mathrm{C}=\mathrm{C}$ str.); ${ }^{1} \mathrm{H} \mathrm{NMR}\left(400 \mathrm{MHz}, \mathrm{CDCl}_{3}\right) \delta_{\mathrm{H}} 7.65(1 \mathrm{H}, \mathrm{m}$, H-6), 7.88 (1H, m, H-7), 7.97 (1H, d, J=8.25 Hz, H-8), 8.07 $(1 \mathrm{H}, \mathrm{d}, J=8.25 \mathrm{~Hz}, \mathrm{H}-5), 8.74(1 \mathrm{H}, \mathrm{s}, \mathrm{H}-4)$, and $10.54(1 \mathrm{H}, \mathrm{s}$, $\mathrm{H}-9) ;{ }^{13} \mathrm{C}$ NMR $\left(100 \mathrm{MHz}, \mathrm{CDCl}_{3}\right) \delta_{\mathrm{C}} 126.3$ (C-1), 126.5 (C-8), 128.2 (C-6), 128.6 (C-4a), 129.7 (C-5), 133.6 (C-7), 140.3 (C-4), 149.6 (C-8a), 150.1 (C-2), and 189.1 (C-9).

2.2.3. Synthesis of 2-Methoxyquinoline-3-carbaldehyde (5). A $100 \mathrm{~mL}$ two-neck round-bottom flask was charged with methanol $(10 \mathrm{~mL}), \mathrm{N}, \mathrm{N}$-dimethylformamide $(10 \mathrm{~mL}), 2$ chloroquinoline-3-carbaldehyde $(0.5 \mathrm{~g}, 0.0026 \mathrm{~mol})$, and potassium carbonate $(0.67 \mathrm{~g}, 0.0048 \mathrm{~mol})$; the mixture was refluxed using water condenser for 6 hours; and the progress of reaction was monitored with TLC. After completion of the reaction, methanol was removed by distillation, allowed to cool to room temperature, and then added to $100 \mathrm{~mL}$ icecold water. The solid product was collected by fractional distillation and washed with excess ice-cold water. The amount of product was $0.44 \mathrm{~g}$. Gray powder; yield $90.2 \%$; mp $106-108^{\circ} \mathrm{C} ; R_{\mathrm{f}}=0.32$ ( $n$-hexane:EtOAc $=9: 1 ; \mathrm{UV}-\mathrm{Vis} \lambda \max$ $(\mathrm{MeOH}) 295 \mathrm{~nm}$; IR( $\left.U \mathrm{~cm}^{-1}, \mathrm{KBr}\right): 3065.4$ (aromatic C-H str.), 2919.3 (aliphatic C-H str.), 2847 (aliphatic C-H str.), 1673 (aldehyde $\mathrm{C}=\mathrm{O}$ str.), 1620 (quinoline $\mathrm{C}=\mathrm{N}$ str.), 1599 and 1579 (aromatic $\mathrm{C}=\mathrm{C}$ str.); ${ }^{1} \mathrm{H}$ NMR $\left(400 \mathrm{MHz}, \mathrm{CDCl}_{3}\right)$ $\delta_{\mathrm{H}} 4.22(3 \mathrm{H}, \mathrm{s}, \mathrm{H}-10), 7.45(1 \mathrm{H}, \mathrm{t}, J=7.3 \mathrm{~Hz}, \mathrm{H}-7), 7.76(1 \mathrm{H}, \mathrm{t}$, $J=7.7 \mathrm{~Hz}, \mathrm{H}-6), 7.85(2 \mathrm{H}, \mathrm{m}, \mathrm{H}-5, \mathrm{H}-8), 8.60(1 \mathrm{H}, \mathrm{s}, \mathrm{H}-4)$, and $10.49(1 \mathrm{H}, \mathrm{s}, \mathrm{H}-9) ;{ }^{13} \mathrm{C} \mathrm{NMR}\left(100 \mathrm{MHz}, \mathrm{CDCl}_{3}\right) \delta_{\mathrm{C}} 55.9(\mathrm{C}-$ 10), 120.0 (C-3), 124.4 (C-6), 125.1 (C-4a), 127.1 (C-8), 129.8 (C-5), 132.6 (C-7), 140.0 (C-3), 149.0 C-8a), 161.2 (C-2), and 189.4 (C-9).

2.2.4. Synthesis of 2-Ethoxyquinoline-3-carbaldehyde (6). A $100 \mathrm{~mL}$ two-neck round-bottom flask was charged with 2-chloroquinoline-3-carbaldehyde (0.5 g, $0.0026 \mathrm{~mol})$, 
potassium carbonate $(0.6 \mathrm{~g}, 0.0044 \mathrm{~mol})$, ethanol $(10 \mathrm{~mL})$, and $\mathrm{N}, \mathrm{N}$-dimethylformamide $(10 \mathrm{~mL})$, and the necks were fitted with water condenser and stopper. The mixture was refluxed for 5 hours and the progress of the reaction was monitored with TLC. At the end, the ethanol was removed by distillation, and the remaining cooled mixture was poured into $100 \mathrm{~mL}$ crushed ice water. The solid mass was collected by suction filtration. Yield 67.3\%; white powder; $\mathrm{mp} 63-65^{\circ} \mathrm{C}, R_{\mathrm{f}}=0.38$ ( $n$-hexane $\left.: \mathrm{EtOAc}=9: 1\right)$, UV-Vis $\lambda \max (\mathrm{MeOH}) 300 \mathrm{~nm}$; IR $\left(\mathrm{U} \mathrm{cm}^{-1}, \mathrm{KBr}\right) 3429$ (OH str.), 3055 (aromatic C-H str.), 2930.9 (aliphatic C-H str.), 2874.45 (aliphatic $\mathrm{C}-\mathrm{H}$ ), 1683 ( $\mathrm{C}=\mathrm{O}$ str.), 1621 (quinoline $\mathrm{C}=\mathrm{N}$ str.), 1589.6 and 1566 (aromatic $\mathrm{C}=\mathrm{C}$ str.); ${ }^{1} \mathrm{H}$ NMR $\left(400 \mathrm{MHz}, \mathrm{CDCl}_{3}\right) \delta_{\mathrm{H}} 1.53\left(3 \mathrm{H}, \mathrm{t}, J_{12}=7.05 \mathrm{~Hz}, \mathrm{H}-11\right), 4.89$ $\left(2 \mathrm{H}, \mathrm{q}, J_{12}=7.05 \mathrm{~Hz}, \mathrm{H}-10\right), 7.43(1 \mathrm{H}, \mathrm{t}, J=7.3 \mathrm{~Hz}, \mathrm{H}-7)$, $7.72(1 \mathrm{H}, \mathrm{t}, J=7.3 \mathrm{~Hz}, \mathrm{H}-6) 7.84(2 \mathrm{H}, \mathrm{d}, J=8.37 \mathrm{~Hz}, \mathrm{H}-8$, $\mathrm{H}-5), 8.59(1 \mathrm{H}, \mathrm{s}, \mathrm{H}-4)$, and $10.61(1 \mathrm{H}, \mathrm{s}, \mathrm{H}-9) ;{ }^{13} \mathrm{C} \mathrm{NMR}$ $\left(100 \mathrm{MHz}, \mathrm{CDCl}_{3}\right) \delta_{\mathrm{H}} 14.5(\mathrm{C}-11), 62.4(\mathrm{C}-10) 120.0(\mathrm{C}-3)$, 124.3 (C-4a), 124.9 (C-6), 127.3 (C-8), 129.8 (C-5), 132.5 (C-7), 139.7 (C-4), 149.1 (C-8a), 161.2 (C-2), and 189.07 (C-9).

2.2.5. Synthesis of 2-Thiocyanatoquinoline-3-carbaldehyde (7). Potassium thiocyanate $(0.24 \mathrm{~g}, 0.0024 \mathrm{~mol}), 2$-chloro8 -methyl quinoline-3-carbaldehyde $(0.5 \mathrm{~g}, 0.0024 \mathrm{~mol})$, and potassium carbonate $(0.65 \mathrm{~g}, 0.0047 \mathrm{~mol})$ were added to $100 \mathrm{~mL}$ two-neck round-bottom flask containing N,Ndimethylformamide $(20 \mathrm{~mL})$. A water condenser was placed on one of its neck, and the other was closed with glass stopper and then refluxed for 3 hours, and the progress of the reaction was followed by TLC. The system was cooled to room temperature and poured into $50 \mathrm{~mL}$ crushed ice water. The solid product was collected with suction filtration and washed with $10 \mathrm{~mL}$ cold water. Yield $83.6 \%$; orange powder; $\mathrm{mp} 134-136^{\circ} \mathrm{C} ; R_{\mathrm{f}}=0.44$ ( $n$-hexane: $\mathrm{EtOAc}=2: 1)$; UV-Vis $\lambda \max (\mathrm{MeOH}) 255 \mathrm{~nm}$; IR $\left(\mathrm{Ucm}^{-1}\right.$, KBr) 3045 (aromatic C-H str.), 2919.9 (aliphatic C-H str.), 2182 (cyanide $\mathrm{S}-\mathrm{C} \equiv \mathrm{N}$ str.), 1683 (aldehyde $\mathrm{C}=\mathrm{O}$ str.), 1610 (quinoline $\mathrm{C}=\mathrm{N}$ str.), 1572 (aromatic $\mathrm{C}=\mathrm{C}$ str.), 1512 and 1340 (O=N-O str.); ${ }^{1} \mathrm{H}$ NMR $\left(400 \mathrm{MHz}, \mathrm{CDCl}_{3}\right) \delta_{\mathrm{H}} 7.50$ $(1 \mathrm{H}, \mathrm{d}, J=7.8 \mathrm{~Hz}, \mathrm{H}-8), 7.61(1 \mathrm{H}, \mathrm{d}, J=8.9 \mathrm{~Hz}, \mathrm{H} 6), 7.72$ $(1 \mathrm{H}, \mathrm{d}, J=8.8 \mathrm{~Hz}, \mathrm{H}-7), 7.85(1 \mathrm{H}, \mathrm{d}, J=8.9 \mathrm{~Hz}, \mathrm{H}-5), 8.74$ $(1 \mathrm{H}, \mathrm{s}, \mathrm{H}-4), 10.65(1 \mathrm{H}, \mathrm{s}, \mathrm{H}-9) ;{ }^{13} \mathrm{C}$ NMR $(100 \mathrm{MHz}$, $\left.\mathrm{CDCl}_{3}\right) \delta_{\mathrm{C}} 87.6(\mathrm{C}-10), 121.1$ (C-3, C-6), 122.4 (C-6, C-8), 125.8 (C-4), 127.7 (C-5), 129.7 (C-7), 132.8 (C-8a), 135.6 (C-4a), 163.6 (C-2), and 188.9 (C-9).

2.2.6. Synthesis of 2-Chloroquinoline-3-carboxylic Acid (8). Sodium hydroxide solution $(1 \mathrm{~mL}, 10 \%)$ was added to a suspension of 2-chloroquinoline-3-carbaldehyde $(0.5 \mathrm{~g}$, $0.0026 \mathrm{~mol})$ in water $(20 \mathrm{~mL})$. Then a saturated solution of potassium permanganate in water was added dropwise until a definite purple color remains after shaking the solution. The mixture was acidified with $10 \%$ sulfuric acid, and a saturated oxalic acid was added to destroy the excess permanganate solution. The carboxylic acid precipitate was isolated by suction filtration. Yield 59.3\%; white powder, $\mathrm{mp} 202-204^{\circ} \mathrm{C}$;
$\mathrm{Rf}=0.63$ (EtOAc: dichloromethane: methanol $=(3: 2: 3)$; UV-Vis $\lambda \max (\mathrm{MeOH}) 280 \mathrm{~nm}$; IR $\left(U \mathrm{~cm}^{-1}, \mathrm{KBr}\right)$ 3440-2483 (broad band, acid $\mathrm{CO}_{2}-\mathrm{H}$ str), 1725 (C=O str), 1621 (quinoline $\mathrm{C}=\mathrm{N}$ str.), 1540 and 1496.6 (aromatic $\mathrm{C}=\mathrm{C}$ str.); ${ }^{1} \mathrm{H}$ NMR $(400 \mathrm{MHz}, \mathrm{DMSO}-\mathrm{d} 6), \delta_{\mathrm{H}} 7.72(1 \mathrm{H}, \mathrm{t}$, $J=7.0 \mathrm{~Hz}, \mathrm{H}-6), 7.92(1 \mathrm{H}, \mathrm{t}, J=7.0 \mathrm{~Hz}, \mathrm{H}-7), 7.98(1 \mathrm{H}, \mathrm{d}$, $J=7.8 \mathrm{~Hz}, \mathrm{H}-8), 8.15(1 \mathrm{H}, \mathrm{d}, J=7.8 \mathrm{~Hz}, \mathrm{H}-5), 8.93(1 \mathrm{H}, \mathrm{s}$, $\mathrm{H}-4) ;{ }^{13} \mathrm{C}$ NMR (100 MHz, DMSO-d6) $\delta_{\mathrm{C}} 130.65$ (C-3), 131.10 (C-4a), 132.83 (C-8a), 133.21 (C-5), 134.50 (C-6), 137.92 (C-7), 146.93 (C-4), 151.62 (C-8), 152.5 (C-2), and $170.90(\mathrm{C}-9)$.

2.2.7. Synthesis of 4-Nitrophenol (10). Concentrated sulfuric acid $(5.5 \mathrm{~mL})$ was added to a $100 \mathrm{~mL}$ beaker containing water $(7.5 \mathrm{~mL})$. To the solution, finely powdered p-nitroaniline $(3.5 \mathrm{~g}, 0.025 \mathrm{~mol})$ and $15 \mathrm{~g}$ of finely crushed ice were added and stirred until the p-nitroaniline converted into a homogeneous paste. It was cooled to $0-5^{\circ} \mathrm{C}$ by immersion of the beaker in crushed ice. A cold solution of sodium nitrite $(1.8 \mathrm{~g})$ in $4 \mathrm{~mL}$ of water was added to it dropwise while keeping temperature below $5^{\circ} \mathrm{C}$ during the diazotization process. While the diazotization reaction was in progress, a mixture of $16.5 \mathrm{~mL}$ concentrated sulfuric acid in $15 \mathrm{~mL}$ of water was heated to just boiling in $100 \mathrm{~mL}$ round flask, and the diazonium solution was added to it dropwise within 5 minutes. After additional 5 minutes of boiling, the mixture was cooled in ice bath while being stirred continuously. The solid mass was collected by suction filtration and washed with $10 \mathrm{~mL}$ of cold water. The crude product was recrystallized in $6 \mathrm{M}$ hydrochloric acid. The yield of yellow crystal product was $2.1 \mathrm{~g}(60 \%)$. The melting point was $112-113^{\circ} \mathrm{C}$ (literature value is $113.8^{\circ} \mathrm{C}$ ). Purity was analyzed with TLC, and its authenticity was ascertained by comparing its melting point with literature value.

2.2.8. Synthesis of 2-Nitro-12H-chromeno[2,3-b]quinolin-12one (11). p-Nitrophenol (0.34 g, $0.0024 \mathrm{~mol}), 2$-chloro-8methylquinoline-3-carbaldehyde $\quad(0.5 \mathrm{~g}, \quad 0.0024 \mathrm{~mol})$, potassium carbonate $(0.67 \mathrm{~g}, 0.0047 \mathrm{~mol})$, and moist copper powdered $(0.1 \mathrm{~g}, 0.0016)$ were added to a $100 \mathrm{~mL}$ two-neck round-bottom flask containing N,N-dimethylformamide $(20 \mathrm{~mL})$. A water condenser was fitted into one of the necks, and the other one was closed with glass stopper. The mixture was refluxed for 5 hours with the progress followed by TLC. After being cooled to room temperature, it was added to $100 \mathrm{~mL}$ crushed ice water. The solid product was separated by suction filtration and washed with $5 \%$ sodium hydroxide solution $(50 \mathrm{~mL})$. Yield $0.61 \mathrm{~g}$ (81.3\%); yellow powder, $\mathrm{mp} 177-179^{\circ} \mathrm{C} ; R_{\mathrm{f}}=0.67(n$-hexane: EtOAc $=2: 1)$, UV-Vis $\lambda \max (\mathrm{MeOH}) 285 \mathrm{~nm}$; IR $\left(\mathrm{Ucm}^{-1}\right.$, $\mathrm{KBr}) 3055$ (aromatic C-H str.), 1703 (C=O str.), 1615 (quinoline $\mathrm{C}=\mathrm{N}$ str.), 1577 (aromatic $\mathrm{C}=\mathrm{C}$ str.), 1512 and $1340\left(\mathrm{O}=\mathrm{N}-\mathrm{O}\right.$ str.); ${ }^{1} \mathrm{H}$ NMR: $\left(400 \mathrm{MHz}, \mathrm{CDCl}_{3}\right) \delta_{\mathrm{H}} 6.97$ $(2 \mathrm{H}, \mathrm{t}, J=7.4 \mathrm{~Hz}, \mathrm{H}-8, \mathrm{H}-9), 7.04(2 \mathrm{H}, \mathrm{d}, J=8.4 \mathrm{~Hz}, \mathrm{H}-4$, $\mathrm{H}-7), 7.55(2 \mathrm{H}, \mathrm{t}, J=7.4 \mathrm{~Hz}, \mathrm{H}-1, \mathrm{H}-10), 7.96(2 \mathrm{H}, \mathrm{d}$, $J=8.0 \mathrm{~Hz}, \mathrm{H}-3, \mathrm{H}-11) ;{ }^{13} \mathrm{C}$ NMR $\left(100 \mathrm{MHz}, \mathrm{CDCl}_{3}\right) \delta_{\mathrm{C}} 111.4$ 
(C-11a, C-12a), 117.8 (C-1, C-4, C-9), 119.6 (C-7, C-10, C-10a), 131.0 (C-3, C-8), 137.0 (C-2, C-6a, C-11), 162.2 (C4a, C-5a), 175.0 (C-12).

2.2.9. Synthesis of 2-Methylacetanilide (13). To a $250 \mathrm{~mL}$ round-bottom flask, $o$-toluidine $(22 \mathrm{~mL}, 22.2 \mathrm{~g}, 0.207 \mathrm{~mol})$, acetic anhydride $(23 \mathrm{~mL}, 24.84 \mathrm{~g}, 0.24 \mathrm{~mol})$, acetic acid $(23 \mathrm{~mL}, 24.15 \mathrm{~g}, \quad 0.40 \mathrm{~mol})$, and zinc powder $(0.2 \mathrm{~g}$, $0.003 \mathrm{~mol}$ ) were added. The mixture was refluxed for an hour using water condenser. It was cooled to room temperature and added to $200 \mathrm{~mL}$ crushed ice water. The product was collected by suction filtration. Yield $21.2 \mathrm{~g}$ (69\%); white powder; mp $108-110^{\circ} \mathrm{C}$ (Lit. $109-112^{\circ} \mathrm{C}$ ).

2.2.10. Synthesis of 2-Chloro-8-methylquinoline-3-carbaldehyde (14). To a $100 \mathrm{~mL}$ round-bottom flask equipped with drying tube, N,N-dimethylformamide $(20 \mathrm{~mL}, 18.88 \mathrm{~g}$, $0.26 \mathrm{~mol}$ ) was added, and the mixture was cooled to $0^{\circ} \mathrm{C}$ using ice bath. Then phosphorus oxychloride $(70 \mathrm{~mL}$, $115.15 \mathrm{~g}, 0.75 \mathrm{~mol}$ ) was added dropwise from dropping funnel guarded by drying tube which was fitted to flask with adaptor while being stirred by magnetic stirrer for 30 minutes. Next, N-(o-tolyl)acetamide (13.5 g, $0.1 \mathrm{~mol})$ was added to it, the dropper funnel was replaced by air condenser with guarding tube, and the mixture was heated for 22 hours on oil bath at $85-90^{\circ} \mathrm{C}$. After that, it was cooled to room temperature and poured into a beaker containing $400 \mathrm{~mL}$ crushed ice water, while being stirred with glass road. The yellow solid product was collected by suction filtration and washed with cold water. The crude yield was $9.2 \mathrm{~g}(44.77 \%)$, and it was recrystallized in ethyl acetate. The final pure product was $6.8 \mathrm{~g}$ (33.09\%); pale yellow crystal; mp $136-140^{\circ} \mathrm{C} ; \mathrm{Rf}=0.30$ (n-hexane:EtOAc $=9: 1$ ), UV-Vis $\lambda$ max $(\mathrm{MeOH}) 295 \mathrm{~nm}$; IR ( $\left.\mathrm{ucm}^{-1}, \mathrm{KBr}\right) 3223,3025$ (arom-C-H.), 2956 (alip-C-H), 2837 (alip-C-H), 1683.3 (C=O str.), 1621 (quinoline $\mathrm{C}=\mathrm{N}$ str.), 1579 (aromatic $\mathrm{C}=\mathrm{C}$ str.); ${ }^{1} \mathrm{H}$ NMR $\left(400 \mathrm{MHz} ; \mathrm{CDCl}_{3}\right) \delta_{\mathrm{H}} 2.80(3 \mathrm{H}, \mathrm{s}, \mathrm{H}-10), 7.53(1 \mathrm{H}, \mathrm{t}, \mathrm{H}-6)$, 7.70 (1H, d, H-7), 7.78 (1H, d, H-5), 8.70 (1H, s, H-4), 10.6 $(1 \mathrm{H}, \mathrm{s}, \mathrm{H}-9) ;{ }^{13} \mathrm{C} \mathrm{NMR}\left(100 \mathrm{MHz}, \mathrm{CDCl}_{3}\right): \delta_{\mathrm{C}} 17.8(\mathrm{C}-10)$, 126.0 (C-3), 126.5 (C-6), 127.5 (C-5), 127.8 (C-4a), 133.6 (C7), 136.9 (C-8), 140.4 (C-4), 148.7 (C-2), 149.4 (C-8a) and 189.5 (C-1).

2.2.11. Synthesis of 8-Methyl-2-oxoquinoline-3-carbaldehyde (15). 2-Chloro-8-methylquinoline-3-carbaldehyde (0.5 g, $0.0024 \mathrm{~mol})$ was added to a mixture of $6 \mathrm{M} \mathrm{HCl}(10 \mathrm{~mL})$ and glacial acetic acid $(10 \mathrm{~mL})$. The mixture was refluxed for 3 hours, at which the TLC analysis showed complete disappearance of the starting material. Then the acetic acid mixture was removed with distillation under reduced pressure. The solid residue was washed with cold water and allowed to dry in wood cupboard. The amount of the product was $395 \mathrm{mg}$. Yield $86.5 \%$; yellow powder; $\mathrm{mp}$ $176-178^{\circ} \mathrm{C} ; R_{\mathrm{f}}=0.41$ (n-hexane:EtOAc $=1: 1$ ); UV-Vis $\lambda$ max (MeOH) 375 nm; IR (Ucm $\left.{ }^{-1}, \mathrm{KBr}\right) 3429$ (O-H str.), 3179.5 (NH str.), 3023 (aromatic C-H), 2919.8 (aliphatic CH-str'.), 2837.2 (aliphatic C-H) 1673 (C=O str.), 1610 (quinoline
$\mathrm{C}=\mathrm{N}$ str.), 1558 and 1465 (aromatic $\mathrm{C}=\mathrm{C}$ str.); ${ }^{1} \mathrm{H}$ NMR $\left(400 \mathrm{MHz} ; \mathrm{CDCl}_{3}\right) \delta_{\mathrm{H}} 2.56(3 \mathrm{H}, \mathrm{s}, \mathrm{C}-10), 7.23(1 \mathrm{H}, \mathrm{t}$, $J=7.5 \mathrm{~Hz}, \mathrm{H}-6), 7.51(1 \mathrm{H}, \mathrm{d}, J=7.32 \mathrm{~Hz}, \mathrm{H}-7) 7.61(1 \mathrm{H}, \mathrm{m}$, $J=7.7 \mathrm{~Hz}, \mathrm{H}-5), 8.49(1 \mathrm{H}, \mathrm{s}, \mathrm{H}-4)$ and $10.48(1 \mathrm{H}, \mathrm{s}, \mathrm{H}-9) ;{ }^{13} \mathrm{C}$ NMR $\left(100 \mathrm{MHz}, \mathrm{CDCl}_{3}\right) \delta_{\mathrm{C}} 16.7$ (C-10), 117.9 (C-6), 123.3 (C-3, C-8), 129.1 (C-4a, C-7), 135.0 (C-5), 139.1 (C-8a), 144.2 (C-4), 162.7 (C-2), 190.00 (C-9).

2.2.12. Synthesis of (2-Methoxy-8-methylquinolin-3-yl) methanol (16). A gram of sodium $(0.043 \mathrm{~mol})$ was dissolved in $10 \mathrm{~mL}$ methanol, and 2-chloro-8-methylquinoline-3carbaldehyde $(0.5 \mathrm{~g}, 0.0024 \mathrm{~mol})$ and $10 \mathrm{~mL}$ of N,N-dimethylformamide were added to it. The mixture was refluxed for 6 hours, at which TLC analysis showed complete disappearance of the aldehyde. After removal of methanol using distillation, the remaining content was cooled to room temperature and added to $100 \mathrm{~mL}$ ice-cold water. The precipitate was collected by fractional distillation. Yield 53\%; gray powder, $\mathrm{mp} 98-99^{\circ} \mathrm{C}$; $\mathrm{Rf}=0.51$ (n-hexane:EtOAc $=3$ : 1), UV-Vis $\lambda \max (\mathrm{MeOH}) 315 \mathrm{~nm}$; IR $\left(\mathrm{Ucm}^{-1}, \mathrm{KBr}\right): 3470$ (br-alcohol CHO-H str.), 3013 (aromatic C-H str.), 2930.9 (aliphatic C-H str.), 1625 (quinoline $\mathrm{C}=\mathrm{N}$ str.), 1589.6 and 1475.5 (aromatic $\mathrm{C}=\mathrm{C}$ str.); ${ }^{1} \mathrm{H}$ NMR $\left(400 \mathrm{MHz} \mathrm{CDCl}_{3}\right) \delta_{\mathrm{H}}$ 2.80 (3H, s, H-10), 4.11 (3H, s, H-9), 4.79 (2H, s, H-1), 7.28 $(1 \mathrm{H}, \mathrm{t}, J=7.58 \mathrm{~Hz}, \mathrm{H}-6), 7.42(1 \mathrm{H}, \mathrm{d}, J=7.0 \mathrm{~Hz}, \mathrm{H}-7), 7.58$ $(2 \mathrm{H}, \mathrm{d}, J=8.34 . \mathrm{Hz}, \mathrm{H}-5), 7.86(1 \mathrm{H}, \mathrm{s}, \mathrm{H}-4) ;{ }^{13} \mathrm{C} \mathrm{NMR}$ $\left(100 \mathrm{MHz} \mathrm{CDCl}_{3}\right) \delta_{\mathrm{C}} 18.1(\mathrm{C}-10), 51.3$ (C-9), $61.9(\mathrm{C}-1)$, 123.8 (C-3), 124.1 (C-6), 124.2 (C-4a), 125.0 C-5), 129.4 (C7), 135.1 (C-8), 135.9 (C-4), 144.7 (C-8a), 160.2 (C-2).

2.2.13. Synthesis of (2-Ethoxy-8-methylquinolin-3-yl)methanol (17). Sodium ( $1 \mathrm{~g}, 0.043 \mathrm{~mol})$ was dissolved in ethanol $(10 \mathrm{~mL})$, and $0.5 \mathrm{~g}(0.0024 \mathrm{~mol})$ of 2 -chloroquinoline-3carbaldehyde and $10 \mathrm{~mL}$ of $\mathrm{N}, \mathrm{N}$-dimethylformamide were added to it. The mixture was refluxed for 5 hours, at which TLC analysis showed complete disappearance of the aldehyde. The ethanol was removed by distillation, and the remaining content was cooled to room temperature and added to $100 \mathrm{ml}$ cold water. The precipitate was collected by fractional distillation. Yield $82.7 \%$; dull brown; $\mathrm{mp} 85-87^{\circ} \mathrm{C}$; $R_{\mathrm{f}}=0.54$ (n-hexane:EtOAc $\left.=3: 1\right)$; UV-Vis $\lambda \max (\mathrm{MeOH})$ $315 \mathrm{~nm}$; IR ( $\left.\mathrm{ucm}^{-1}, \mathrm{KBr}\right) 3502-3148$ (OH str.), 3025 (aromatic C-H str.), 2930.9 (aliphatic C-H str.), 1625 (quinoline $\mathrm{C}=\mathrm{N}$ str.), 1582 (aromatic $\mathrm{C}=\mathrm{C}$ str.); ${ }^{1} \mathrm{H}$ NMR $(400 \mathrm{MHz}$; $\left.\mathrm{CDCl}_{3}\right) \delta_{\mathrm{H}} 1.5(3 \mathrm{H}, \mathrm{t}, J=7.01 \mathrm{~Hz}, \mathrm{H}-10), 2.74(3 \mathrm{H}, \mathrm{s}, \mathrm{H}-11)$ $4.63(2 \mathrm{H}, \mathrm{q}, J=7.01 \mathrm{~Hz}, \mathrm{H}-9), 4.48(2 \mathrm{H}, \mathrm{s}, \mathrm{H}-1), 7.26(1 \mathrm{H}, \mathrm{t}$, $J=7.04 \mathrm{~Hz}, \mathrm{H}-6), 7.47(1 \mathrm{H}, \mathrm{d}, J=6.89 \mathrm{~Hz}, \mathrm{H}-7), 7.56(1 \mathrm{H}, \mathrm{d}$, $J=7.80 \mathrm{~Hz}, \mathrm{H}-5), 7.93(1 \mathrm{H}, \mathrm{s}, \mathrm{H}-4) ;{ }^{13} \mathrm{C} \mathrm{NMR}(100 \mathrm{MHz}$, $\left.\mathrm{CDCl}_{3}\right) \delta_{\mathrm{C}} 13.7(\mathrm{C}-10), 19.3(\mathrm{C}-11), 61.5$ (C-1), 61.8 (C-9), 123.0 (C-9), 124.2 (C-6), 124.90 (C-4a), 125.0 (C-5), 130.3 (C-7), 135.0 (C-8), 135.8 (C-4), 144.7 (C-8a), 158.3 (C-2).

2.3. Antibacterial Activity. Antibacterial activities of the synthesized compounds were tested using the paper discdiffusion method. In the process, two Gram-positive bacteria (Bacillus subtilis ATCC6633 and Staphylococcus aureus ATCC25923) and two Gram-negative bacteria 

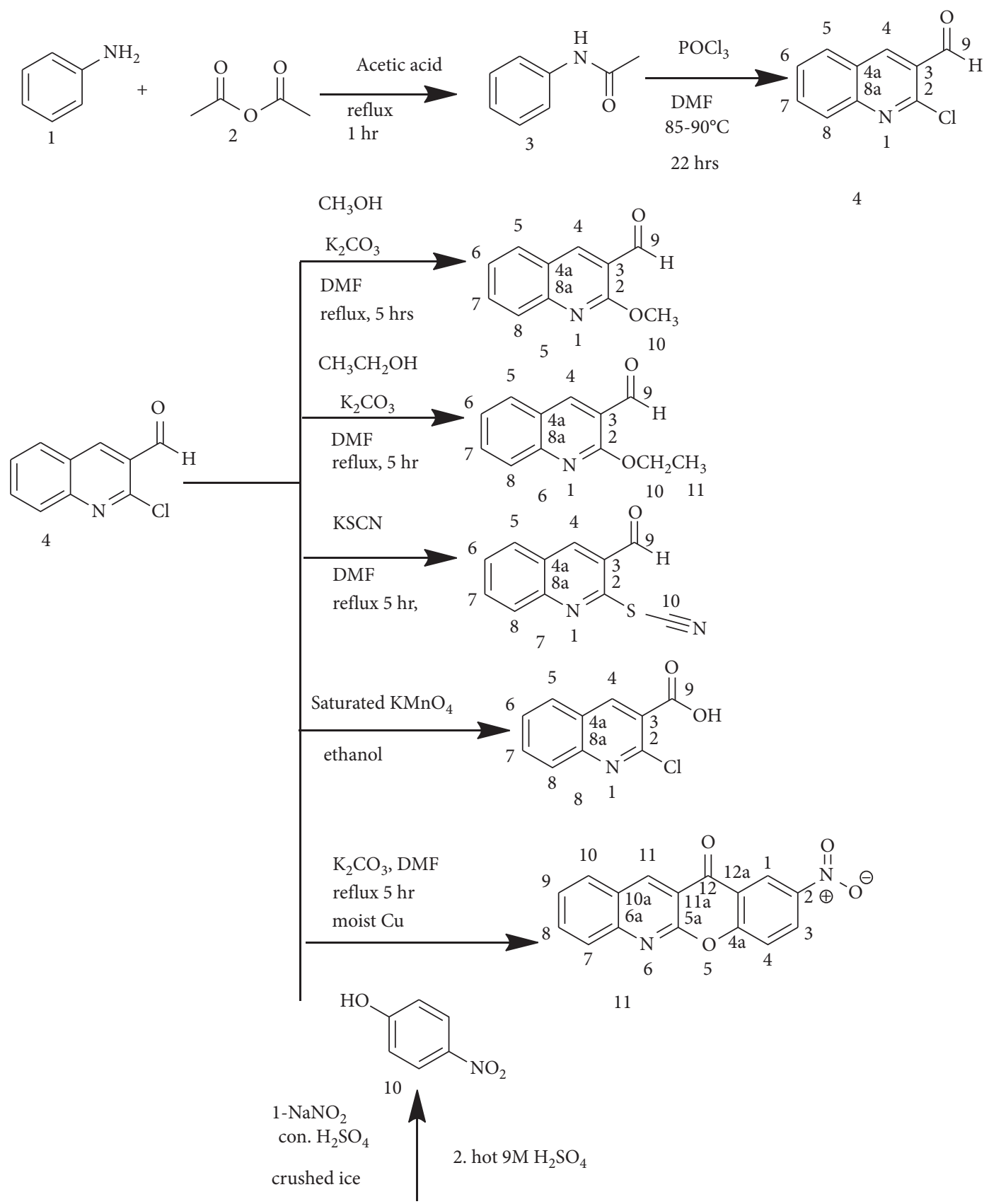

$0-5^{\circ} \mathrm{C}$<smiles>Nc1ccc([N+](=O)[O-])cc1</smiles>

Scheme 1: Synthesis of 2-chloroquinoline-3-carbaldehyde and its derivatives.

(Escherichia coli ATCC 25922 and Pseudomonas aeruginosa ATCC 27853) were used to evaluate the antibacterial activities. The medium was prepared from molten nutrient and Müeller-Hinton agar. Ciprofloxacin was the standard drug used as positive control while DMSO was used as negative control. The four bacterial strains were tested with 300 and $500 \mu \mathrm{g} / \mathrm{mL}$ concentration using paper disc-diffusion method. Each of the ten compounds was dissolved in DMSO at concentrations of 300 and $500 \mu \mathrm{g} /$
$\mathrm{mL}, 6 \mathrm{~mm}$ diameter Whatman filter paper discs were soaked with $1 \mathrm{~mL}$ solution of the above two concentrations for each compound, and then these saturated paper discs were inoculated at the center of each Petri dish having bacterial lawn in triplicate. The plates were incubated at $37^{\circ} \mathrm{C}$ for $48 \mathrm{~h}$, and the inhibition zone that appeared around the paper disc in each plate was determined by measuring the diameter of the inhibition zone. 

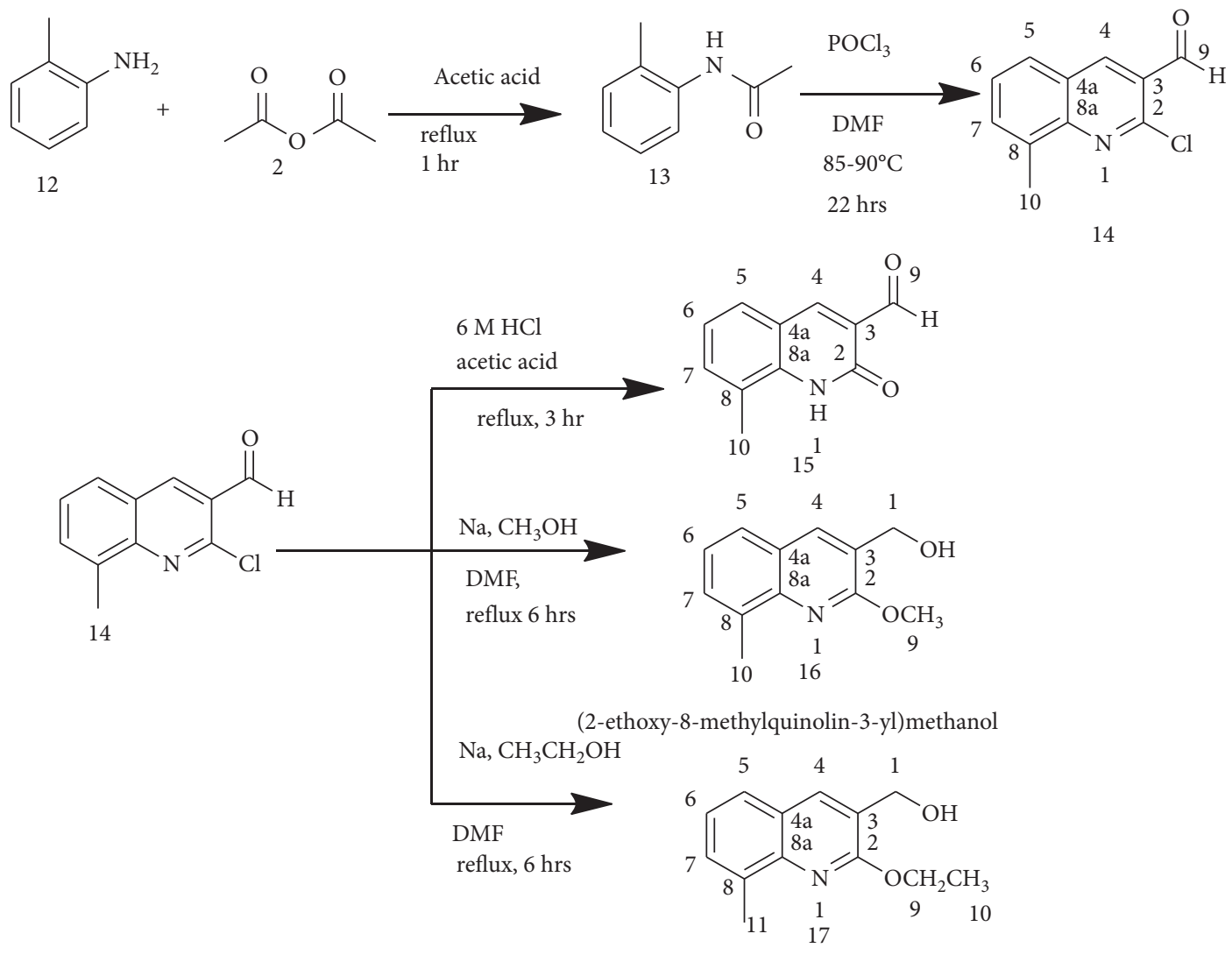

SCHEME 2: Synthesis of 2-chloro-8-methylquinoline-3-carbaldehyde and its derivatives.

2.4. Radical Scavenging Activity of the Synthesized Compounds. The radical scavenging activity of the synthesized compounds was evaluated with 1,1-diphenyl-2-picryl hydrazyl (DPPH). In the process, $0.04 \mathrm{mg} / \mathrm{mL}$ solution of DPPH in methanol was prepared; $1 \mathrm{~mL}$ of this solution was poured into $4 \mathrm{~mL}$ of the synthesized samples in methanol to furnish four different concentrations $(12.5,25,50,100 \mu \mathrm{g} /$ $\mathrm{mL}$ ); and control was made by adding $1 \mathrm{~mL}$ of the DPPH solution to $4 \mathrm{~mL}$ of methanol, while $4 \mathrm{~mL}$ methanol was used as a blank. The mixtures were shaken and allowed to stand at $37^{\circ} \mathrm{C}$ for $30 \mathrm{~min}$ in dark oven, and absorbance was recorded at $517 \mathrm{~nm}$ using double beam UV-Vis spectrophotometer. Ascorbic acid was used for reference standard in similar concentration as above. Percentage inhibition of $\mathrm{DPPH}$ radical was determined using the following equation:

$$
\% \text { inhibition }=\frac{A_{o}-A_{1}}{A_{o}} \times 100,
$$

where $A_{o}$ is the absorbance of control reaction and $A_{1}$ is the absorbance in presence of test or standard sample [21].

2.5. Molecular Docking Analysis of the Synthesized Compounds. AutoDock Vina with standard protocol was used to dock the proteins (PDB ID: 6F86; PDB ID: 2XCT) and synthesized compounds (4-17) into the active site of proteins [22]. The chemical structures of compounds 4-17 were drawn using ChemOffice tool (ChemDraw 16.0) assigned with proper $2 \mathrm{D}$ orientation, and energy of each molecule was minimized using ChemBio3D. The energyminimized ligand molecules were then used as input for AutoDock Vina, in order to carry out the docking simulation [22]. The crystal structures of receptor molecule $E$. coli gyrase B (PDB ID : 6F86) and $S$. aureus gyrase complex with ciprofloxacin and DNA (PDB ID:2XCT) were downloaded from protein data bank. The protein preparation was done using the reported standard protocol [23] by removing the cocrystallized ligand, selected water molecules, and cofactors; the target protein file was prepared by leaving the associated residue with protein using Auto Preparation of target protein file AutoDock 4.2 (MGLTools 1.5.6). The graphical user interface program was used to set the grid box for docking simulations. The grid was set so that it surrounds the region of interest in the macromolecule. The docking algorithm provided with AutoDock Vina was used to search for the best docked conformation between ligand and protein [22-24]. During the docking process, a maximum of nine conformers were considered for each ligand. The conformations with the most favorable (least) free binding energy were selected for analyzing the interactions between the target receptor and ligands by Discovery Studio Visualizer and PyMOL. The ligands are represented in different color; $\mathrm{H}$-bonds and the interacting residues are represented in ball and stick model representation. 


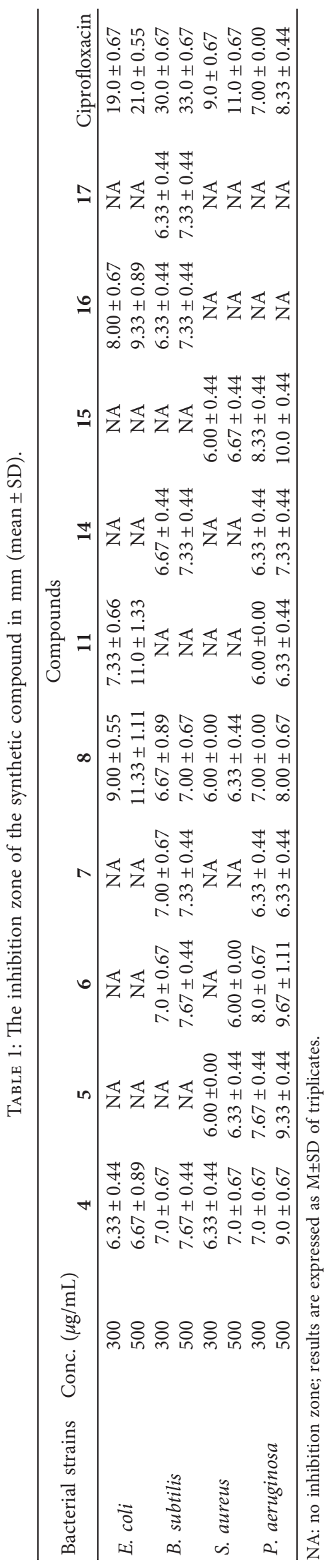




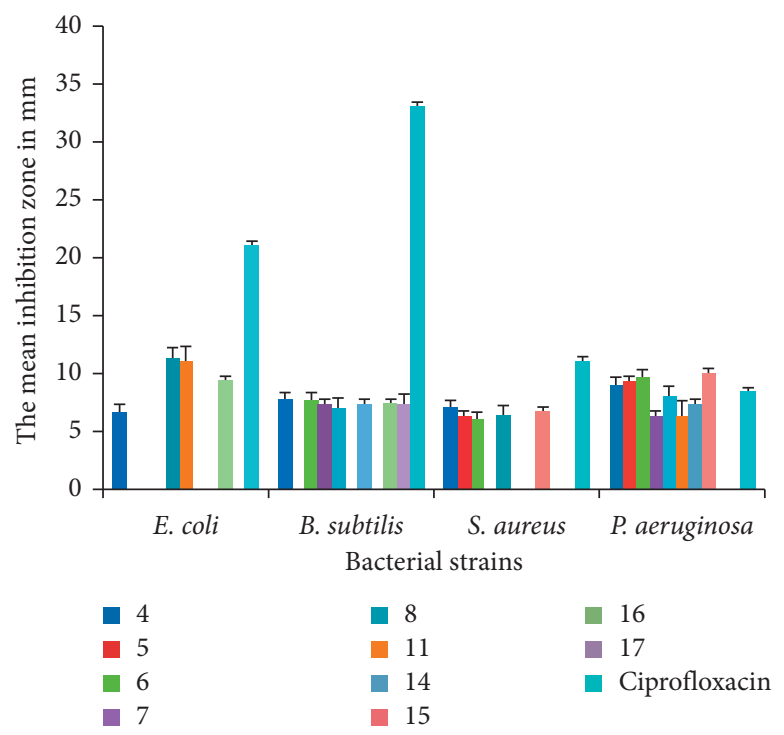

Figure 1: The inhibition zone of the synthetic compounds in mm (mean \pm SD) at $500 \mu \mathrm{g} / \mathrm{mL}$.

\section{Results and Discussion}

3.1. Chemistry. In an attempt to generate quinoline derivatives which have antibacterial properties, various quinoline derivatives were prepared using various reaction conditions. In the process, $\mathrm{N}$-(o-tolyl)acetamide and acetanilide were prepared by refluxing the corresponding aniline in acetic acid and acetic anhydride mixtures. Then 2-chloroquinoline-3-carbaldehyde and 2-chloro-8-methylquinoline-3carbaldehyde were prepared from the acetanilide by the Vilsmeier approach. The chlorine in position 2 of quinolines was substituted by various nucleophiles by refluxing 2-chloroquinoline-3-carbaldehyde and 2-chloro8-methylquinoline-3-carbaldehyde in N,N-dimethylformamide with various nucleophilic reagents in basic medium. Potassium carbonate was used to induce the basic medium. Refluxing 2-chloro-8-methylquinoline-3-carbaldehyde in $6 \mathrm{M} \mathrm{HCl}$ and acetic acid $(1: 1)$ mixture afforded 8 -methyl-2oxoquinoline-3-carbaldehyde. The carbaldehyde functional group of quinoline was oxidized to carboxylic acid by permanganate method and was subsequently reduced to alcohol using metallic sodium. The overall sequence of reactions used in the synthesis of various targeted quinoline derivatives are illustrated in Schemes 1 and 2.

The structure elucidation of the synthesized compounds was accomplished using UV-Vis, FTIR, and NMR spectroscopic methods.

3.2. Antibacterial Activity. Quinolines are pharmacologically active compounds used to treat various life threatening diseases. In an attempt to find out lead compounds against bacteria, a series of quinoline derivatives have been synthesized and subsequently evaluated for their antibacterial activities against various strains of bacterial pathogens. The results obtained are depicted in Table 1 and Figure 1.
The above data shows all synthesized compounds displayed medium to good activity against two or more bacterial strains. The mean inhibition zones ranged from the lowest $(6 \mathrm{~mm}$ at $300 \mu \mathrm{g} / \mathrm{mL})$ to the highest $(11.3 \mathrm{~mm}$ at $500 \mu \mathrm{g} / \mathrm{mL})$. Three of the ten compounds, 8, 11, and 16, showed good activities against Escherichia coli, among which $\mathbf{1 1}$ and 8 revealed better activities with mean inhibition zone of $11.00 \pm 1.33$ and $11.33 \pm 1.11 \mathrm{~mm}$ diameter at $500 \mu \mathrm{g} / \mathrm{mL}$, respectively. Seven of the ten compounds $(4,6,8,7,14,16$, and 17) (Figure 1) showed antibacterial activity against $\mathrm{Ba}$ cillus subtilis, but maximum inhibition zone $(7.67 \pm 0.44 \mathrm{~mm})$ was observed in compounds $\mathbf{4}$ and $\mathbf{6}$. None of the synthetic compounds demonstrated activity against Staphylococcus aureus except 4, 5, 8, and 15 which showed slight activity. Among the synthetic compounds, 4, 5, 6, and 15 displayed moderate activity against Pseudomonas aeruginosa, and the maximum inhibition zone was $10.00 \pm 0.44 \mathrm{~mm}$ for compound 15 but only $8.33 \pm 0.44 \mathrm{~mm}$ for ciprofloxacin at the same concentration $(500 \mu \mathrm{g} / \mathrm{mL})$. Compounds 4 and 8 displayed moderate to good activity against all tested bacterial species, while compound $\mathbf{1 7}$ showed no activity against all tested organisms except Bacillus subtilis with inhibition zones of $6.33 \pm 0.44 \mathrm{~mm}$ and $7.33 \pm 0.44 \mathrm{~mm}$ at concentrations of 300 and $500 \mu \mathrm{g} / \mathrm{mL}$, respectively.

3.3. Radical Scavenging Activity of the Synthetic Compounds. DPPH assay was widely used to assess the ability of compounds as scavengers of free radicals and hence evaluate the antioxidant activity of synthetics compounds or phytochemicals. Compounds exhibiting antioxidant activity reduced the absorbance at $517 \mathrm{~nm}$, which is due to DPPH radical in addition to their ability to turn the purple colored DPPH to yellow. In this work, the radical scavenging activity of the synthesized compounds was evaluated using DPPH, and the findings are depicted in Table 2. 


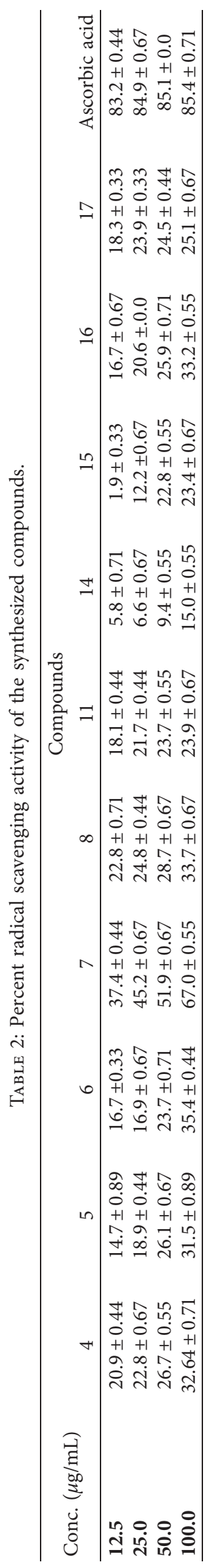




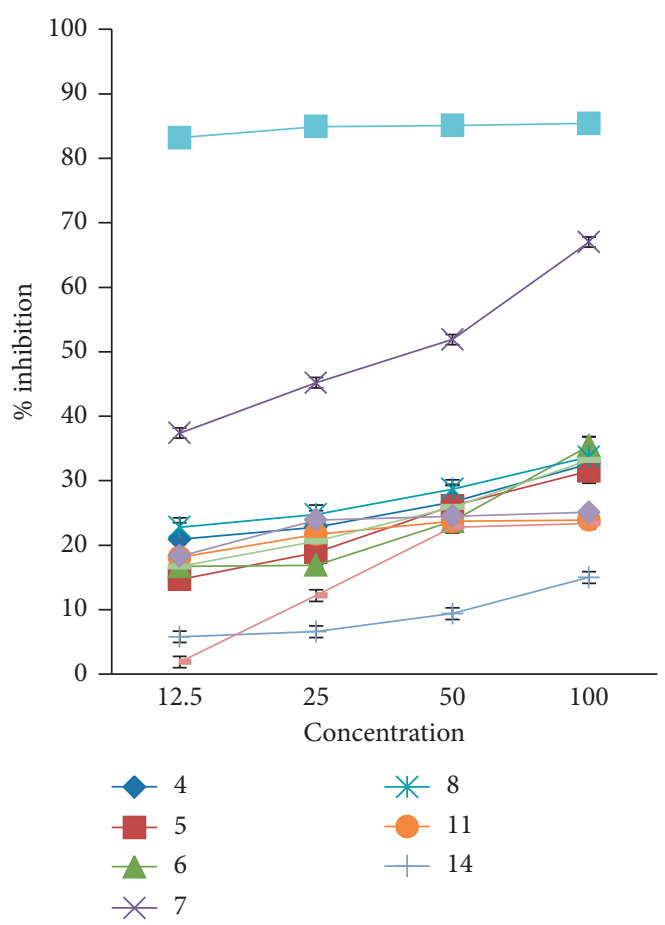

FIgURE 2: Percentage inhibition of DPPH radical by the synthetic compounds.

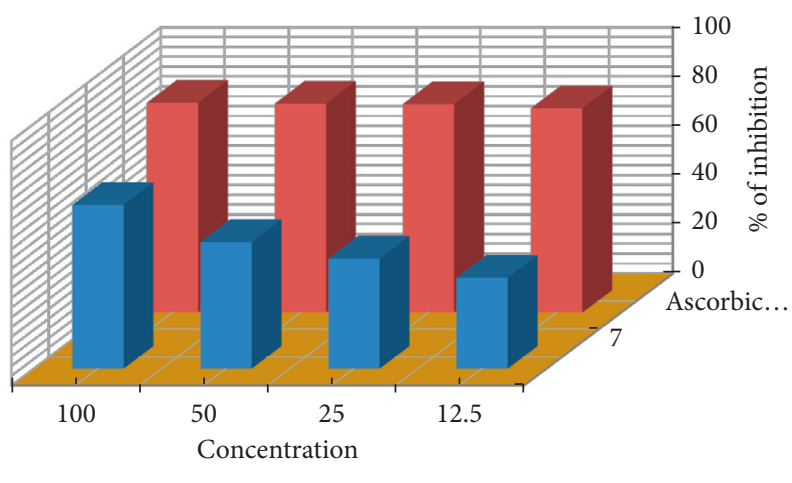

- 7

Figure 3: Comparison of $\%$ inhibition of compound 7 with ascorbic acid.<smiles></smiles><smiles>CC=Cc1cc2ccccc2nc1C(=O)c1cc2ccccc2cc1N(c1ccccc1)N(SC#N)c1c([N+](=O)[O-])cc([N+](=O)[O-])cc1[N+](=O)[O-]</smiles><smiles>O=Cc1cnc2ccccc2c1</smiles>

Scheme 3: Proposed mechanism of action of compound 7.

The DPPH radical scavenging activity of the synthesized compounds was compared with ascorbic acid which is used as positive control, and the result is presented in Figure 2.

Compound 7, which displayed better radical scavenging activity in the present work, has been elaborated in comparison with ascorbic acid using 3D diagram (Figure 3).
The data in Table 2 and Figure 2 reveal that nine of the synthetic compounds showed moderate antioxidant activities, while compound 7 (Figure 3) exhibited better antioxidant activity $(67 \%$ radical scavenging activity at $100 \mu \mathrm{g} / \mathrm{mL}$ concentration) among them all. 1,1-Diphenyl-2-picrylhydrazyl (DPPH) is a stable free radical accepting hydrogen 
TABLE 3: Molecular docking value of compounds 4-17 against E. coli DNA gyrase B.

\begin{tabular}{lccc}
\hline Compounds & $\begin{array}{c}\text { Affinity } \\
(\mathrm{kcal} / \mathrm{mol})\end{array}$ & H-bond & Receptor interactions \\
\hline $\mathbf{4}$ & -6.2 & Asp-73 & Val-43, Val-71, Ile-78, Ala-47 \\
$\mathbf{5}$ & -6.2 & Asp-73, Thr-165, Gly-77 & Ile-94, Ile-78 \\
$\mathbf{6}$ & -6.4 & Gly-77, Thr-165 & Asp-73, Ile-94, Ile-78, Ala-47 \\
$\mathbf{7}$ & -6.3 & Asn-46, Thr-165, Gly-77 & Asp-73, Val-43, Val-167, Ala-47 \\
$\mathbf{8}$ & -6.3 & Asn-46 & Asp-73, Arg-76, Ala-47, Glu-50, Gly-77, Ile-78, Pro-79, Gly-75, Thr-165 \\
$\mathbf{1 1}$ & -7.3 & Arg-76, Asn-46, Gly-77, Thr-165 & Asp-73, Ile-78, Ile-94, Pro-79, Glu-50, Gly-75 \\
$\mathbf{1 4}$ & -6.3 & - & Ile-78, Val-167, Val-120 \\
$\mathbf{1 5}$ & -6.2 & - & Ala-47, Asn-46, Ile-78, Thr-165, Val-167 \\
$\mathbf{1 6}$ & -6.0 & Asp-73 & Ile-78 \\
$\mathbf{1 7}$ & -6.3 & Asp-73, Gly-77 & Ala-47, Glu-50, Ile-78, Pro-79, Thr-165 \\
Ciprofloxacin & -6.9 & Asp-73, Arg-76, Asn-46 & Ala-47, Ile-78, Ile-94, Pro-79, Glu-50, Gly-77 \\
\hline
\end{tabular}
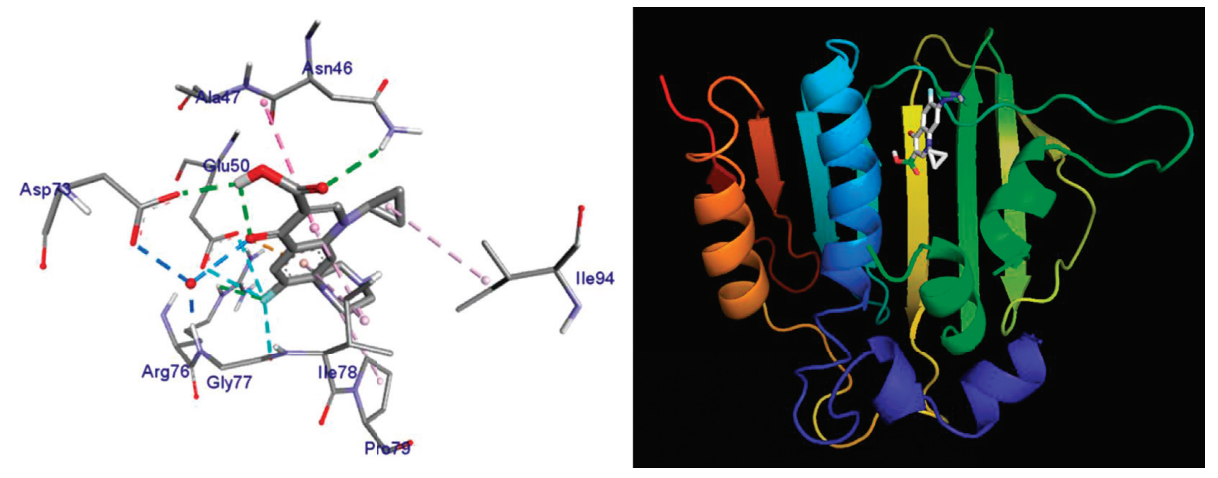

Figure 4: The binding interactions of ciprofloxacin against E. coli DNA gyrase B (PDB ID : 6F86).

from a corresponding donor, which causes it to lose the characteristic deep purple $\left(\lambda_{\max } 517 \mathrm{~nm}\right)$ color. In compound 7 , there is no such easily transferable hydrogen; however, sulfur of thiocyanate functional group may donate an electron to lone pair electron on the nitrogen atom to form bond with sulfur (Scheme 3).

3.4. In Silico Molecular Docking Evaluation. In general, antimicrobial agents target the key components of bacterial metabolism to disable the bacteria such as cell-walls, DNA gyrase, DNA-directed RNA polymerase, protein synthesis, and enzymes. DNA gyrase, an enzyme belonging to a member of bacterial topoisomerase, controls the topology of DNA during transcription, replication, and recombination by introducing transient breaks to both DNA strands [25-27]. In this regard, bacterial DNA gyrase is essential for bacterial survival and therefore necessary to be exploited as an antibacterial drug target [28]. Therefore, in the present study, the molecular docking analysis of the synthesized compounds was carried out to investigate their binding pattern with DNA gyrase and compare them with standard inhibitor (ciprofloxacin). The synthesized compounds (4-17) were found to have minimum binding energy ranging from -6.2 to $-7.3 \mathrm{kcal} / \mathrm{mol}$ (Table 3 ), with the best result achieved using compound $11(-7.3 \mathrm{kcal} / \mathrm{mol})$. The binding affinity, $\mathrm{H}$-bond, and residual interaction of ten compounds and ciprofloxacin were summarized in Table 3. Compared to ciprofloxacin, the synthesized compounds (4-17) showed similar residual interactions profile with amino acid residues Ile-94, Pro-79 Glu-50, Gly-77, Ile-78, and Ala-47 and H-bond with Asp-73, Arg-76, and Asn-46. Compounds 5, 6, and 7 have additional hydrogen bonding interaction with amino acid residue Thr-165. The compounds 4 (Val-43, Val-71), 7 (Val-167), 14 (Val-120 and Val-167), and 15 (Val-167) have shown additional hydrophobic interaction with amino acid residues. The residual amino acid interactions of synthesized ligands (except 14 and 15) with DNA gyrase (6f86) in this study were well in agreement with the previously reported binding modes that include the crucial interactions between the ligand, Asp-73, and the water molecule [23]. The in silico interaction results match the in vitro analysis of the synthesized compounds; 4 (-6.2 kcal/mol), $11(-7.3 \mathrm{kcal} /$ $\mathrm{mol}), 8(-6.3 \mathrm{kcal} / \mathrm{mol})$, and $16(-6.0 \mathrm{kcal} / \mathrm{mol})$ showed good activities against $E$. coli, among which compounds 8 $(-6.3 \mathrm{kcal} / \mathrm{mol})$ and $11(-7.3 \mathrm{kcal} / \mathrm{mol})$ revealed better activity. The compounds $\mathbf{1 4}$ and $\mathbf{1 5}$ docking results partially matched the ciprofloxacin interactions with amino acid residues. Based on the in silico molecular docking analysis results, compounds $\mathbf{8}$ and $\mathbf{1 1}$ showed comparable residual interactions and docking score of ciprofloxacin. Therefore, compound 11 might have the best antibacterial agents among the compounds reported herein. The binding 


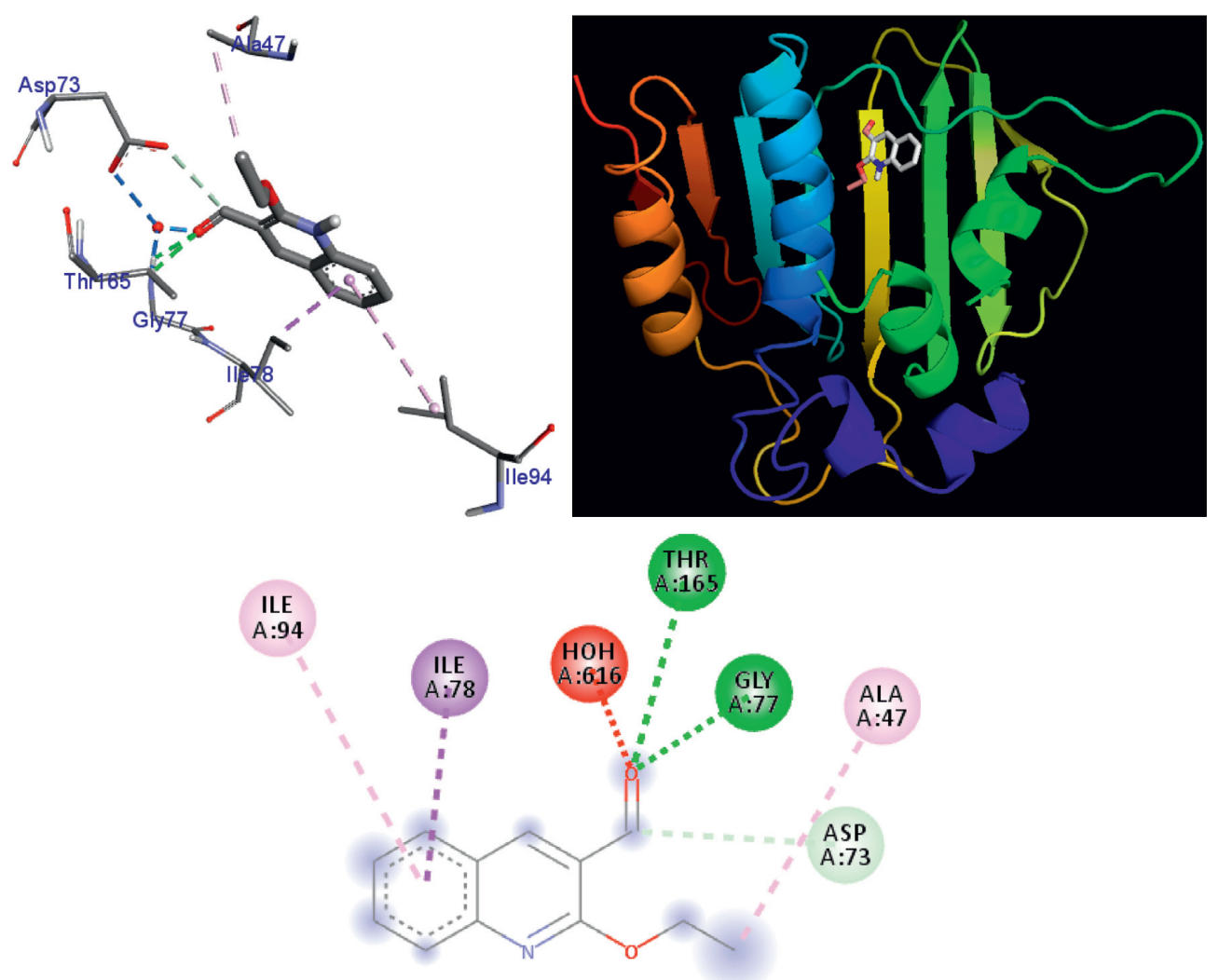

Figure 5: The binding interactions of compound 6 against E. coli DNA gyrase B (PDB ID : 6F86).
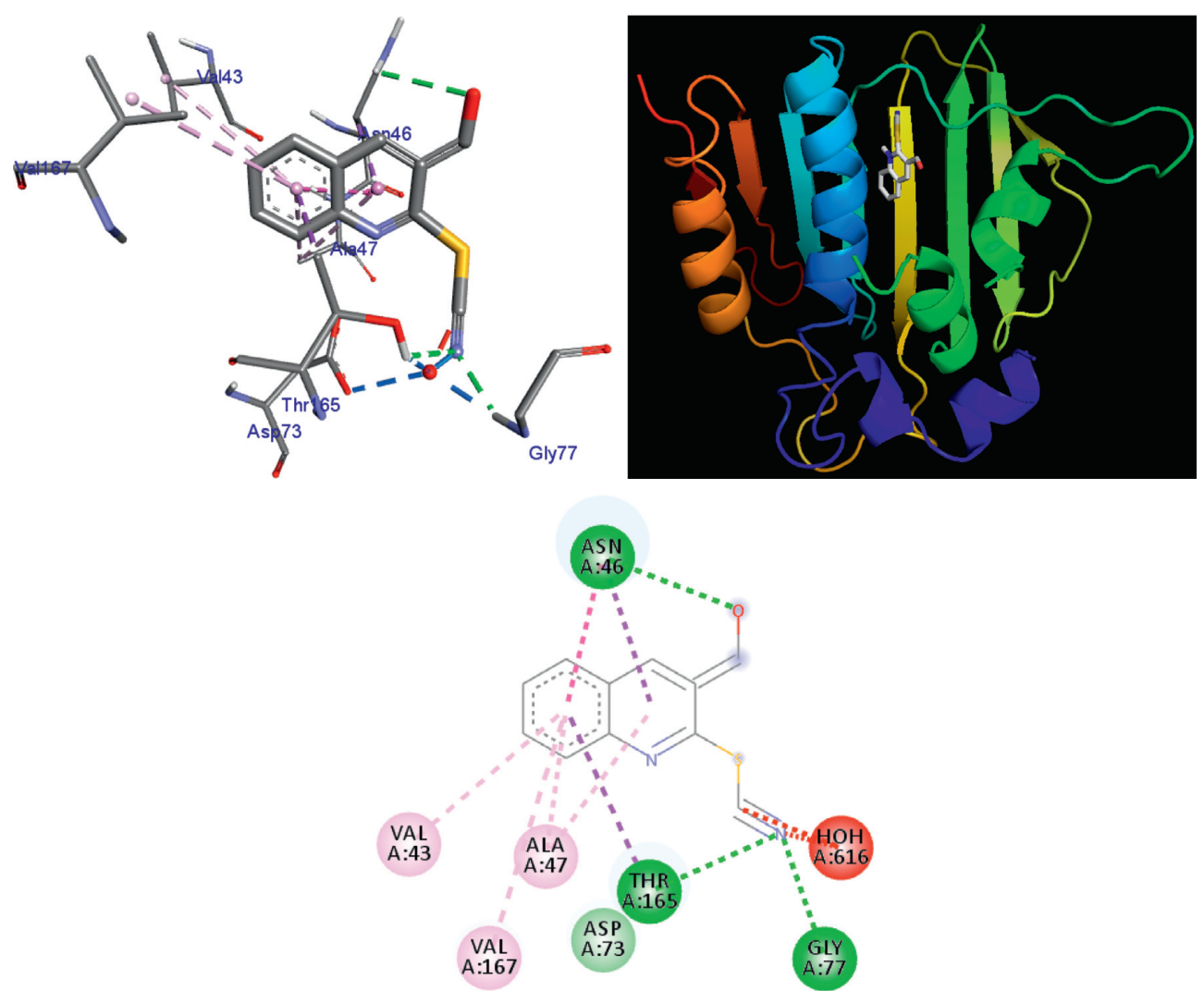

FIgURE 6: The binding interactions of compound 7 against E. coli DNA gyrase B (PDB ID : 6F86). 

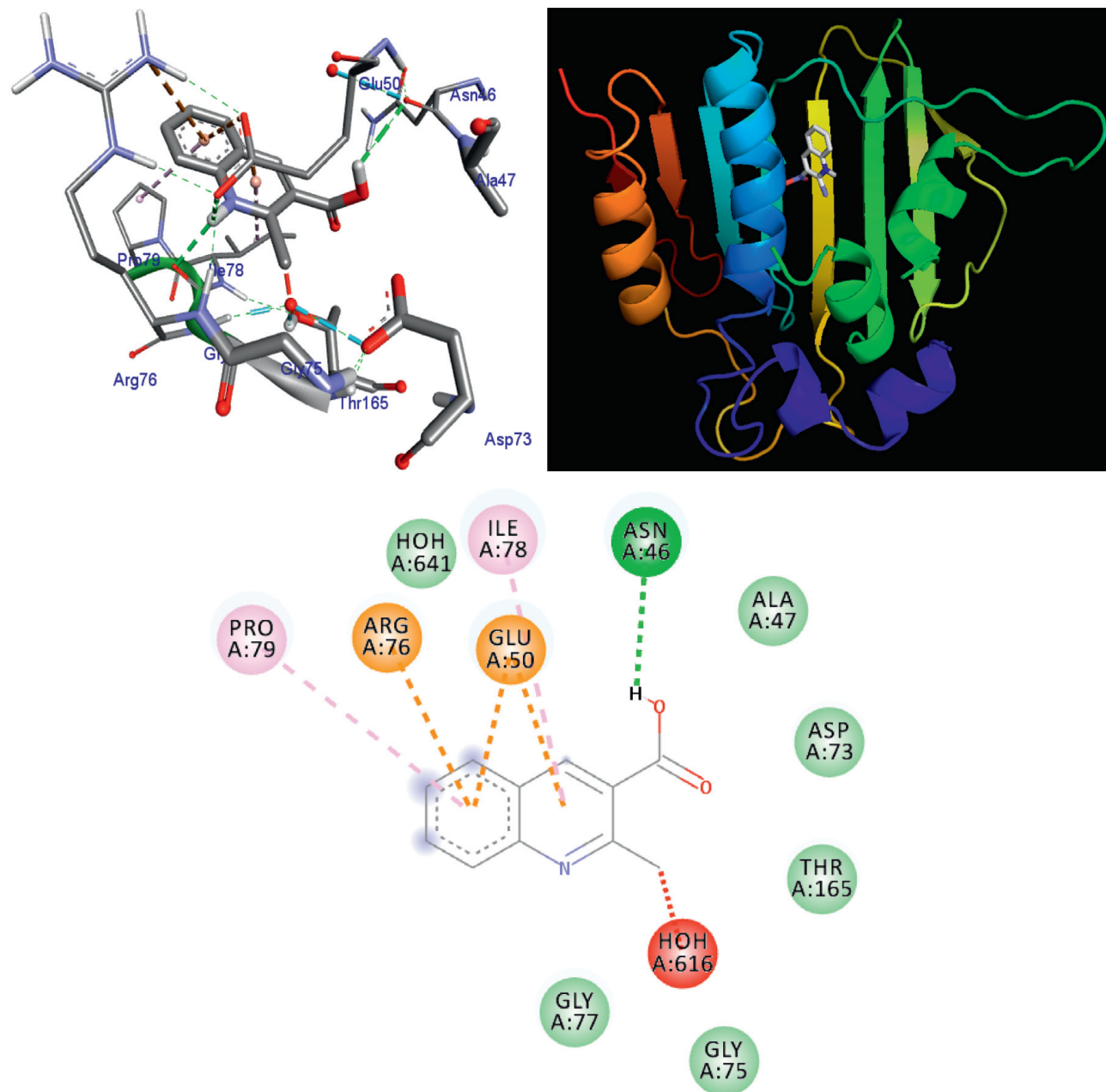

Figure 7: The binding interactions of compound 8 against E. coli DNA gyrase B (PDB ID :6F86).

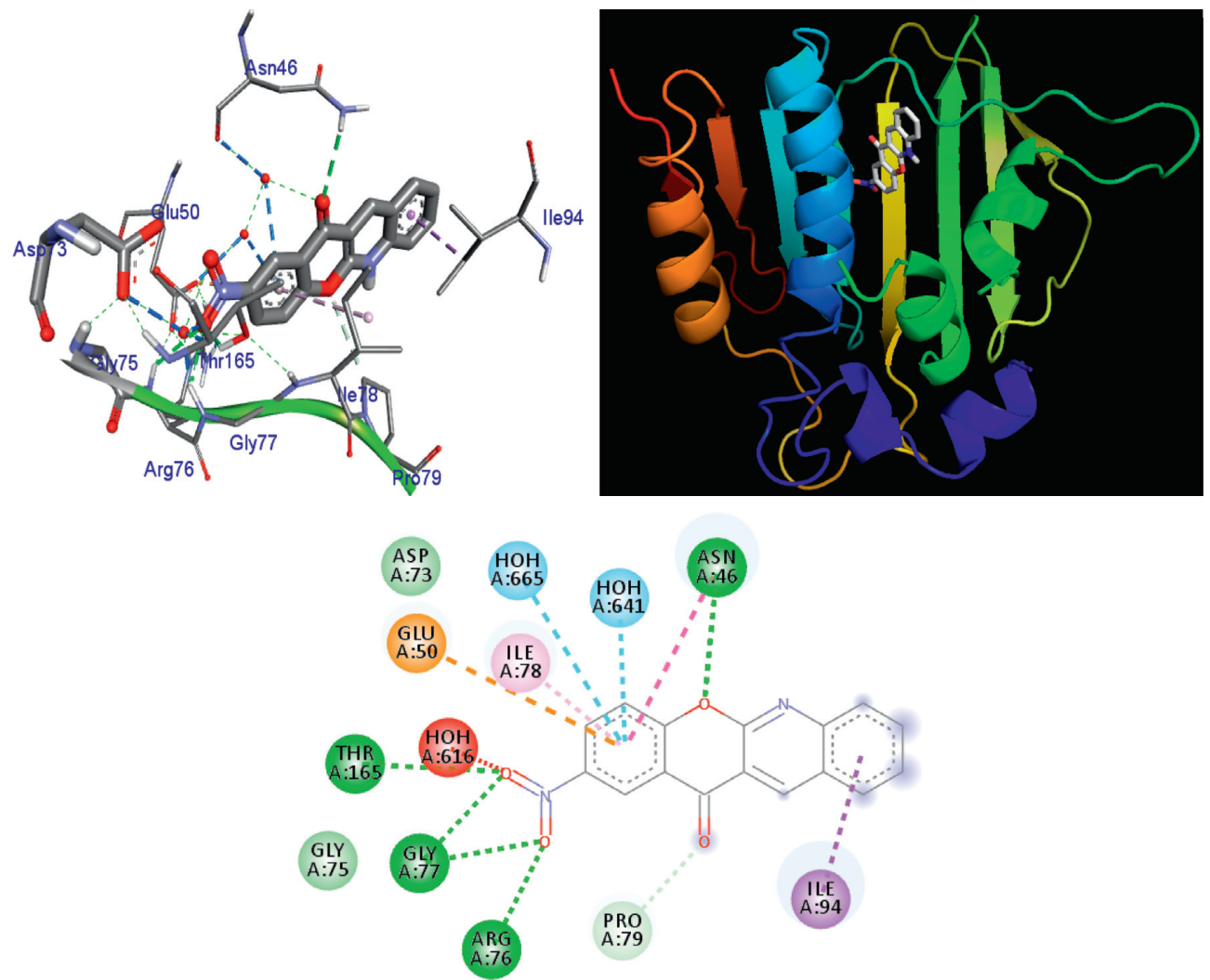



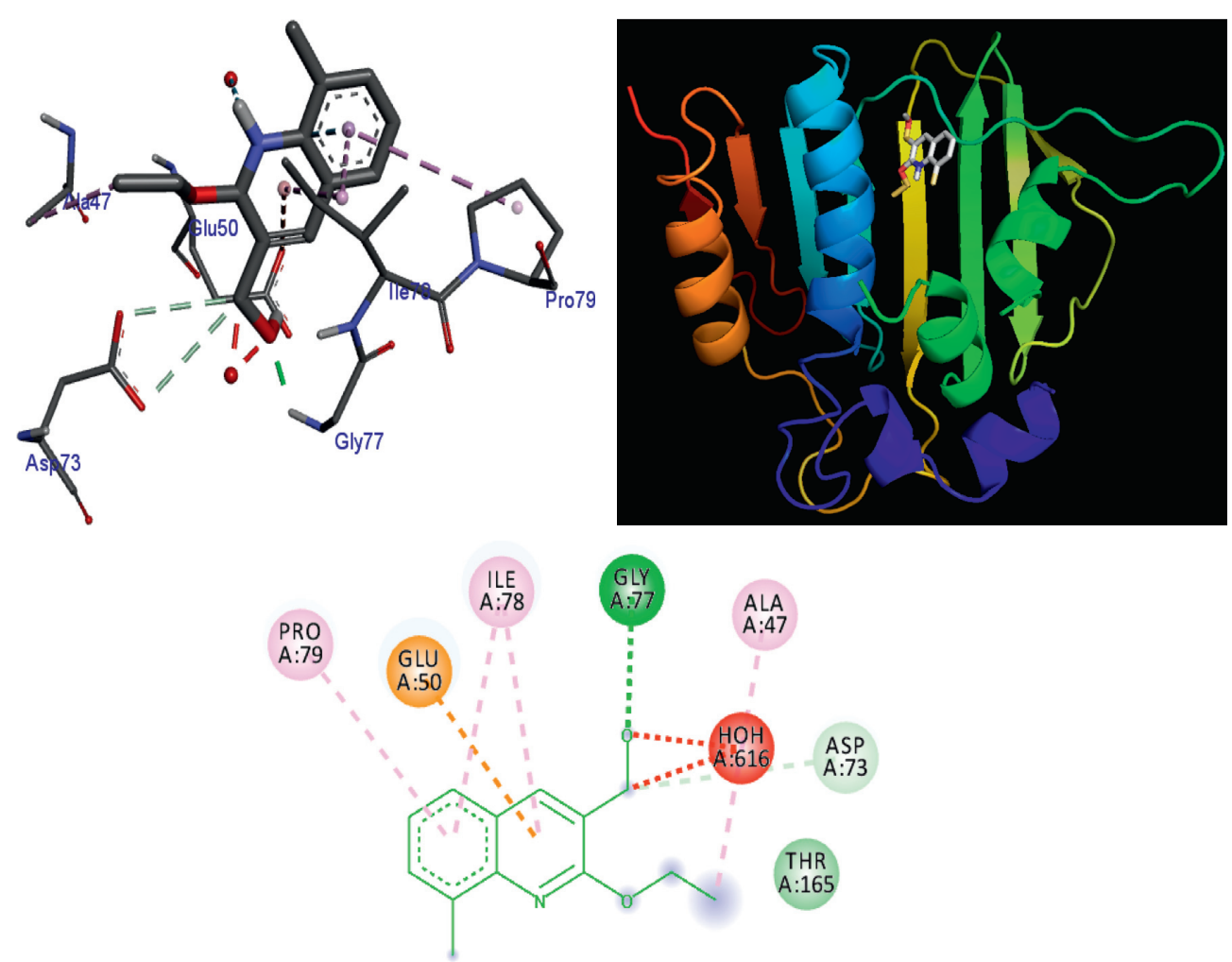

FIgURE 9: The binding interactions of compound 17 against E. coli DNA gyrase B (PDB ID : 6F86).

affinity, H-bond, and residual interaction of ten compounds were summarized in Table 3.

The 3-dimensional binding interaction of compounds 6 , $7, \mathbf{8}, \mathbf{1 1}, 17$ and ciprofloxacin against E. coli gyrase B complex is illustrated in Figures 4-9. The docking results of compounds 4, 5, 14, 15, and 16 against E. coli gyrase B complex and compounds 4-17 against $S$. aureus gyrase B complex are given as supplementary data.

\section{Conclusion}

The quinoline heterocycle is a useful scaffold to develop bioactive molecules. In the present work, we synthesized series of quinolin derivatives by application of Vilsmeier-Haack reaction. Various nucleophiles were introduced into 2-chloroquinoline-3-carbaldehyde and 2-chloro-8methylquinoline-3-carbaldehyde by substitution of chlorine using different reaction conditions. The carbaldehyde functional group was further manipulated to carboxylic acid using potassium permanganate method and reduced to alcohols with metallic sodium. All synthesized compounds were characterized by TLC, melting point, ${ }^{1} \mathrm{H} \mathrm{NMR},{ }^{13} \mathrm{C} \mathrm{NMR}$, and UV-Vis spectroscopy. The antibacterial activities of the synthesized compounds were screened by the disc-diffusion method against two Gram-negative and two Gram-positive bacteria, and most of them were found to have moderate activities against the bacterial strains used for the screening. Among them, compounds $\mathbf{6}$ and 15 exhibited maximum activity against Pseudomonas aeruginosa compared to the standard drug ciprofloxacin. The in silico molecular docking study of the synthesized compounds was performed to assess the binding mode of these compounds against DNA gyrase B (PDB ID: 6F86), and the result was in good harmony with antibacterial assay result. Generally, the synthesized compounds have potential of antibacterial activity and can be further optimized to serve as lead compounds.

\section{Data Availability}

The data used to support the findings of this study are included within the manuscript and also submitted as Supplementary Materials.

\section{Conflicts of Interest}

The authors assert that there are no conflicts of interest regarding the publication of this paper.

\section{Acknowledgments}

The authors are thankful to Adama Science and Technology University for funding this research.

\section{Supplementary Materials}

The ${ }^{1} \mathrm{H}$ NMR and ${ }^{13} \mathrm{C}$ NMR spectra of the synthesized compounds. Figure 1: ${ }^{1} \mathrm{H} \mathrm{NMR}(400 \mathrm{MHz}, \mathrm{CDCl} 3)$ spectrum of 2-chloroquinoline-3-carbaldehyde (4). Figure $2:{ }^{13} \mathrm{C}$ NMR (100 MHz, CDCl3) spectrum of 2-chloroquinoline-3-carbaldehyde (4). Figure 3: ${ }^{1} \mathrm{H}$ NMR (400 MHz, $\mathrm{CDCl} 3$ ) spectrum of 2-methoxyquinoline-3-carbaldehyde (5). 
Figure 4: ${ }^{13} \mathrm{C}$ NMR $(100 \mathrm{MHz}, \mathrm{CDCl} 3)$ spectrum of 2methoxyquinoline-3-carbaldehyde (5). Figure $5:{ }^{1} \mathrm{H}$ NMR (400 MHz, CDCl3) spectrum of 2-ethoxyquinoline-3-carbaldehyde (6). Figure $6:{ }^{13} \mathrm{C}$ NMR $(100 \mathrm{MHz}, \mathrm{CDCl} 3)$ spectrum of 2-ethoxyquinoline-3-carbaldehyde (6). Figure 7: ${ }^{1} \mathrm{H}$ NMR (400 MHz, DMSO-d6) spectrum of 2-thiocyanatoquinoline-3carbaldehyde. Figure 8: ${ }^{1} \mathrm{H}$ NMR $(400 \mathrm{MHz}$, DMSO-d6) spectrum of 2-chloroquinoline-3-carboxylic acid (8). Figure 9: ${ }^{13} \mathrm{C}$ NMR (100 MHz, DMSO-d6) spectrum of 2-ethoxyquinoline-3-carbaldehyde (8). Figure $10:{ }^{1} \mathrm{H}$ NMR $(400 \mathrm{MHz}$, $\mathrm{CDCl} 3)$ spectrum of 2-nitro-12H-chromeno[2,3-b]quinolin12-one (11). Figure 11: ${ }^{13} \mathrm{C}$ NMR $(100 \mathrm{MHz}, \mathrm{CDCl} 3)$ spectrum of 2-nitro-12H-chromeno[2,3-b]quinolin-12-one (11). Figure 12: ${ }^{1} \mathrm{H}$ NMR (400 MHz; CDCl3) spectrum of 2-chloro-8methylquinoline-3-carbaldehyde (14). Figure $13:{ }^{13} \mathrm{C}$ NMR (100 MHz; $\mathrm{CDCl} 3)$ spectrum of 2-chloro-8-methylquinoline3-carbaldehyde (14). Figure $14:{ }^{1} \mathrm{H}$ NMR (400 MHz; CDCl3) spectrum of 8-methyl-2-oxoquinoline-3-carbaldehyde (15). Figure $15:{ }^{13} \mathrm{C}$ NMR $(100 \mathrm{MHz}$; $\mathrm{CDCl} 3)$ spectrum of 8-methyl2-oxoquinoline-3-carbaldehyde (15). Figure 16: ${ }^{1} \mathrm{H}$ NMR spectrum (400 MHz; $\mathrm{CDCl} 3)$ of (2-methoxy-8-methylquinolin-3-yl)methanol (16). Figure 17: ${ }^{13} \mathrm{C}$ NMR spectrum (100 MHz; CDCl3) of (2-methoxy-8-methylquinolin-3-yl) methanol (16). Figure 18: ${ }^{1} \mathrm{H}$ NMR $(400 \mathrm{MHz} ; \mathrm{CDCl} 3)$ spectrum of (2-ethoxy-8-methylquinolin-3-yl)methanol (17). Figure 19: ${ }^{13} \mathrm{C}$ NMR $(100 \mathrm{MHz}$; CDCl3) spectrum of (2-ethoxy-8-methylquinolin-3-yl)methanol (17). (Supplementary Materials)

\section{References}

[1] K. D. Thomas, A. V. Adhikari, and N. S. Shetty, "Design, synthesis and antimicrobial activities of some new quinoline derivatives carrying 1,2,3-triazole moiety," European Journal of Medicinal Chemistry, vol. 45, no. 9, pp. 3803-3810, 2010.

[2] O. Navneetha, K. Deepthi, A. Muralidha Rao, and T. Jyostn, "A review on chemotherapeutic activities of quinoline," IJPCBS, vol. 7, no. 4, pp. 364-372, 2017.

[3] S. Poonam, K. Kamaldeep, C. Amit, S. RranJdh, and R. Dhawan, "A review on biological activities of quinoline derivatives," Journal of Management, Information Technology and Engineering, vol. 2, no. 1, pp. 1-14, 2016.

[4] M. Emmerson and A. Jnes, "The quinolones: decades of development and use," Journal of Antimicrobial Chemother$a p y$, vol. 51, pp. 13-20, 2003.

[5] G. S. Bisacchi, "Origins of the quinolone class of antibacterials: an expanded "discovery story1," Journal of Medicinal Chemistry, vol. 58, no. 12, pp. 4874-4882, 2015.

[6] P. Sharma, A. Jain, and S. Jain, "Fluoroquinolone antibacterials: a review on chemistry, microbiology and therapeutic prospects," Acta Poloniae Pharmaceutica-Drug Research, vol. 66, no. 6, pp. 587-604, 2009.

[7] G. Sárközy, "Quinolones: a class of antimicrobial agents," Veterinární Medicína, vol. 46, no. 9-10, pp. 257-274, 2001.

[8] N. Riahifard, K. Tavakoli, J. Yamaki, K. Parang, and R. Tiwari, "Synthesis and evaluation of antimicrobial activity of [R4W4K]-Levofloxacin and [R4W4K]-Levofloxacin-Q conjugates," Molecules, vol. 22, no. 6, p. 957, 2017.

[9] C. Y. Hong, "Discovery of gemifloxacin (Factive, LB20304a): a quinolone of new a generation," Il Farmaco, vol. 56, no. 1-2, pp. 41-44, 2001.
[10] A. M. Farghaly, N. S. Habib, M. A. Khalil, O. A. El-Sayed, and A. E. Bistawroos, "Synthesis of novel 2-substituted quinoline derivatives: antimicrobial, inotropic, and chronotropic activities," Archiv der Pharmazie, vol. 323, no. 4, pp. 247-251, 1990.

[11] B. Swamy, Y. Praveen, N. Pramod, B. Shivkumar, H. Shivkumar, and R. Rao, "Synthesis, characterization and anti-inflammatory activity of 3-formyl 2-hydroxy quinoline thiosemicarbazides," Journal of Pharmacy Research, vol. 5, no. 5, pp. 2735-2737, 2012.

[12] N. Khalifa, M. Al-Omar, A. El-Galil, and M. El-Reheem, "Anti-inflammatory and analgesic activities of some novel carboxamides derived from 2-phenyl quinoline candidates," Biomedical Research, vol. 28, no. 2, pp. 869-874, 2017.

[13] S. Gupta and A. Mishra, "Synthesis, characterization \& screening for anti-inflammatory \& analgesic activity of quinoline derivatives bearing azetidinone scaffolds," AntiInflammatory \& Anti-allergy Agents in Medicinal Chemistry, vol. 15, no. 1, 2016.

[14] X. Nqoro, N. Tobeka, and B. Aderibigbe, "Quinoline-based hybrid compounds with antimalarial activity," Molecules, vol. 22, no. 12, p. 2268, 2017.

[15] S. Nara and A. Garlapati, "Design, Synthesis and molecular docking study of hybrids of quinazolin-4(3H)-one as anticancer agents," Ars Pharmaceutica, vol. 59, no. 3, pp. 121-131, 2018.

[16] M. Bingul, O. Tan, C. Gardner et al., "Synthesis, characterization and anti-cancer activity of hydrazide derivatives incorporating a quinoline moiety," Molecules, vol. 21, no. 7, p. 916, 2016.

[17] M. Zemtsova, A. Zimichev, P. Trakhtenberg, Y. Klimochkin et al., "Synthesis and antiviral activity of several quinoline derivatives," Pharmaceutical Chemistry Journal, vol. 45, no. 5, 2011.

[18] M. Zemtsova, A. Zimichev, P. Trakhtenberg, R. Belen'kaya, and E. Boreko, "Synthesis and antiviral activity of 4-quinolinecarboxylic acid hydrazides," Pharmaceutical Chemistry Journal, vol. 42, no. 10, 2008.

[19] P. Miniyar, M. Barmade, and A. Mahajan, "Synthesis and biological evaluation of 1-(5-(2-chloroquinolin-3-yl)-3-phenyl-1H-pyrazol1-yl)ethanone derivatives as potential antimicrobial agents," Journal of Saudi Chemical Society, vol. 19, no. 6, pp. 655-660, 2014.

[20] P. G. Mandhane, R. S. Joshi, P. S. Mahajan, M. D. Nikam, D. R. Nagargoje, and C. H. Gill, "Synthesis, characterization and antimicrobial screening of substituted quiazolinones derivatives," Arabian Journal of Chemistry, vol. 8, no. 4, pp. 474-479, 2015.

[21] A. Ansari, S. Ahmed, M. Waheed, and A. Juned, "Extraction and determination of antioxidant activity of Withania somnifera Dunal," European Journal of Experimental Biology, vol. 3, no. 5, pp. 502-507, 2013.

[22] O. Trott and A. J. Olson, "AutoDock Vina: improving the speed and accuracy of docking with a new scoring function, efficient optimization, and multithreading," Journal of Computational Chemistry, vol. 31, no. 2, pp. 455-461, 2010.

[23] S. Narramore, C. E. M. Stevenson, A. Maxwell, D. M. Lawson, and C. W. G. Fishwick, "New insights into the binding mode of pyridine-3-carboxamide inhibitors of E. coli DNA gyrase," Bioorganic \& Medicinal Chemistry, vol. 27, no. 16, pp. 3546-3550, 2019.

[24] D. Seeliger and B. L. de Groot, "Ligand docking and binding site analysis with PyMOL and Autodock/Vina," Journal of Computer-Aided Molecular Design, vol. 24, no. 5, pp. 417-422, 2010. 
[25] R. Ziraldo, A. Hanke, and S. D. Levene, "Kinetic pathways of topology simplification by Type-II topoisomerases in knotted supercoiled DNA," Nucleic Acids Research, vol. 47, no. 1, pp. 69-84, 2019.

[26] C. J. Dorman and M. J. Dorman, "DNA supercoiling is a fundamental regulatory principle in the control of bacterial gene expression," Biophysical Reviews, vol. 8, no. 3, pp. 209-220, 2016.

[27] A. J. Schoeffler and J. M. Berger, "DNA topoisomerases: harnessing and constraining energy to govern chromosome topology," Quarterly Reviews of Biophysics, vol. 41, no. 1, pp. 41-101, 2008.

[28] Z. Jakopin, J. Ilas, M. Barancokova et al., "Discovery of substituted oxadiazoles as a novel scaffold for DNA gyrase inhibitors," European Journal of Medicinal Chemistry, vol. 130, pp. 171-184, 2017. 